\title{
A Novel Study to Predict Trends and Policies for Mobile Communication in Multienvironment Regions
}

\author{
Shah Jahan Khattak (iD) and Bakhtair Khan \\ Department of Business Administration, Gomal University, DI Khan, KPK, Pakistan \\ Correspondence should be addressed to Shah Jahan Khattak; khattak@ieee.org
}

Received 9 July 2018; Revised 11 October 2018; Accepted 18 October 2018; Published 19 December 2018

Guest Editor: Fawad Zaman

Copyright (c) 2018 Shah Jahan Khattak and Bakhtair Khan. This is an open access article distributed under the Creative Commons Attribution License, which permits unrestricted use, distribution, and reproduction in any medium, provided the original work is properly cited.

\begin{abstract}
The research community has growing interest in the field of mobile phone applications due to its extensive usage in voice, data, video, and their combinations including data-voice and voice-video. The trends of mobile usage have paramount significance to formulate effective policies, to analyze human behavior, reliable prediction, and planning, for development and prosperity of any region in the globe. In this research, we explore the usage of mobile communication to analyze these trends; for this, we select Khyber Pakhtunkhwa (KPK), Pakistan, a multienvironment based on farmers, students, employees, and businessmen. A field survey is carried out by designing a detailed structural questionnaire for viable collection of data to have superior analysis of different multienvironment based classes. A statistical analysis is performed through hypotheses and chi-square test on a large dataset based on sufficient number of observations collected through primary survey for each class. The survey results are provided in number of graphical and numerical illustrations to predict the mobile usage trends, evidently and effectively, of the people of KPK. This study has practical and significant implications in understanding the behavioral intensions of the individuals making policies about mobile phone usage.
\end{abstract}

\section{Introduction}

In today's modern and technological era of science and technology, no one can deny the importance of mobile phones and their usage [1]. Mobile phone has become an indispensable and integral part of our life that was initially considered only a source of communication among masses, but now it has key role in creation of employment opportunities, as well as being vital part of accelerating economic growth of any region [2-5]. The major portion of population are thinking that mobile phone applications not only fulfill their requirements but also mobile phone is the source of polite changes at all levels. [6]. In the last three decades, maximum changes occurred in global economy, and development in communication field has produced effective changes in all sectors. No one can deny the potential of mobile usage in diversified fields of applied science, engineering, and technology; see [7-9] and references cited therein.

The purpose of this research is to find the mobile phone usage and the effect of its usage in multienvironment region of
Khyber Pakhtunkhwa (KPK), Pakistan, as it may have different impacts on different classes. The present study is a part of a descriptive research, which is based on the primary survey method and performed statistics to predict the behavior of all four multienvironment classes based on farmers, students, employees, and business community. In this research, we exploit the usage of mobile communication to analyze these trends in KPK. A field survey is conducted by formulation of a detailed structural questionnaire for the collection of data to have superior analysis of different multienvironment based classes. A statistical analysis is performed by the use of hypotheses based chi-square tests on a dataset of the primary survey. The survey results are represented by number of graphical and numerical illustrations to predict the mobile usage trends, evidently and effectively, of the people of KPK. The results show that most of the students from University of Engineering and Technology (UET), Islamia College University, University of Peshawar, and Agriculture University, Peshawar, KPK, Pakistan, have a unanimous thinking that mobile phone has brought positive change. Moreover, cell 
phone is essential to increase productivity, and at same time, they considered that their fellows have no knowledge of the usage of cell phone at the place of work. This study has paramount significance in understanding the behavioral intensions of the individuals who make policies about mobile phone usage.

The rest of the paper is organized as follows; in Section 2, a brief overview of mobile usage is narrated; Section 3 is dedicated to design methodology; Section 4 presents the results; in Section 5, conclusions with future research direction are listed.

\section{Material and Method}

Nowadays, the world becomes global due to new emerging technologies and development. New development in technological sector has brought change in the living of society. This study aims to find the impact of mobile phone advancement. In small interval of time, mobile phones have increased connectivity among people. Mobile phones have provided them with the opportunity to remain connected irrespective of their locations. Mobile phone connectivity is available at all locations all the time. Mobile phone has positively contributed toward the relationship among the society individuals. Cell phones have increased the access of people to all levels. Life became easy in all fields and it has also some negative effect. Mobile phone has also created problem of ethics. The dependency on the usage of mobile phone has increased among people. Mobile phone has produced unwanted relationship among the Youngers [10]. The impact of mobile phone can be positive or negative.

2.1. Cellular Communication Dependency. Previously, people used mobile phones as status symbol, but nowadays people have great relay on mobile phone in their network with the society. Leung Louis [11] said that in America most of the Youngers having age ranging from twelve to seventeen years have a mobile phones and mobile is very popular in their social network. In early days, the cost of mobile phone was very high in Asia and limited people can afford it. With passage of time, the prices decreased $[9,10]$. These models were heavy in weight and were difficult to carry, but with development new standards were introduced like MMS, Internet, and connectivity which decreased the cost of mobile phones, now available at low prices $[12,13]$.

Nickerson C. [14] described the term leisure boredom which means that all individuals are in search of becoming busy and they have a greater dependency on mobile phones. Most of the Youngers are busy in Internet, MMS, and voice communication when they are free. Its mean that they pass their free time in making calls to friend or playing games with usage of mobile phones. Mobile phones may sometimes take the Youngers into great risk not following the standard procedures. The Youngers have greater dependency on mobile phones [12]. The common observation is that when the people are free, they become bored and they are in search of becoming busy, while violating the rules of usage of mobile phones. This approach was adapted by the people who greatly depend on mobile phone for the purpose of security and business while being connected with their families. The positive contribution of mobile phone is to make call during incident or to make entertainment by using mobile phone [14].

Youngers think that mobile phone has positively contributed in society and make life easy by connecting with others irrespective of locations. [1]. According to report that mobile phones are tremendously used during emergency, which has saved large number of people, mobile phone has become an integral part of human life.

Mobile phone has also positive contribution toward travelling and toward access to those being far away from their offices [1]. A report indicates that $70 \%+$ of people use mobile phone for business activities while minimum percentage of people have personal activities [12].

Nokia Company carried out a survey in year 2001 from three thousand plus people in all over the world under the age of 40 . About $70 \%+$ of people said that they use MMS function most of all from their mobile phone. People have common usage of text messing. Mobile phones are used in making friendship and having connectivity [15]. Initially mobile phones were used for business. [1]. In USA, the engineers pointed out that the land line was invented for the purpose of business and military usage [16]. According to information presented in [17], which shows that in Australia the mobile phone users are Nineteen billion + , the mobile phones adapted by Youngers are very costly. According to information reported in [17], the maximum percentage of Youngers, having age ranging from ten to sixteen years old, and minimum percentage of adults have a personal cell phone. From a survey of [18] globe cellular penetration is up to 3.7 billion and according to estimate most of the population have personal cell phones, which puts about seventy plus percent of world's population in the range of mobile phones [19]. Mobile phones were among the few technologies which spread so rapidly in the world. People use cell phones for different purposes. The same study showed that almost 60 percent of people keep their mobile phones with them all the time wherever they go $[16,17]$. In offices the employers expect that people will be self-responsible and will not use cell phones for personal purposes. Employers usually ask employees to make personal phone use at lunch time or tea break and tell their family and friends not to disturb them during work hours except in case of emergency [20].

2.2. Cellular Communication Dependency and Impact. Development in communication sector has brought revolution in all sections of the world. After 1980, mobile phones replace land lines in developed countries and contributed positively in less developed countries. Mobile phones have great impact on the social life of the society. Males and females have equal opportunities of the usage of mobile phones for network in society. Cell phones are the main tools of production in less developed countries.

Most people use mobile phones for the currency rates, market tendency, and access to abroad [20]. Limited people have thought that mobile phones have negative impact when used in duty places. Small group of people think that mobile phones have increased the chances of access, thus 
having positive impact [20]. Mobile phone has contributed to the GDP of developed countries and produced millions of pounds. Mobile phones have very large percentage of impact on social sector. Mobile phones give satisfaction by providing connectivity at all locations [14]. The role of mobile phone cannot be denied in all types of business. There is full information sharing among the customers and owners in market. The physical distance is reduced among the suppliers and buyers. Many bosses think that the usage of mobile phone at duty places has negative impact and the production is reduced. The employers usually think to ban the mobile phone during the period of production. This has some negative impact because the workers will not be comfortable which will resultantly reduce the production. The policy makers should recommend procedures based on the nature of business and the vision of the employees [19]. For example, the mobile phones should not be permitted during travelling and working hours. The employees in different sections of the company especially in marketing and sales should not be allowed to use mobile phones during working hours. This will result in ignoring the customers. Mobile phones should be silent during meetings and conferences; otherwise, they will create negative impact. Depending on the nature of work, supervision level people should be allowed to coordinate with customers and their coworkers. People at reception desk have different nature of work; they may be allowed to remain in contact with colleagues. Mobile phone has positively contributed toward economic growth through, for example, easy access to market, which reduced the cost of communication and also reduced the travelling cost for physical and face to face meeting.

Mobile phone has different roles in different countries. In Europe, it is used to bring unification and rebuild the economy, while in Finland, it is used as status symbol. The mobile phone in Japan is a fast way of communication, while in Philippine, it is the source of political change.

The mobile phone has reduced the travelling of those people involved in much travelling to reach offices and time limitation is there.

The impact of mobile phone is usually negative including reduction in production and disturbances during working hours based on the receiving of calls and the ring tunes of the mobile phone. For a limited time, the concentration of the worker changes whether he receives a call or ignores it. Mobile phone has a negative effect on the workers if they are in production section. In developed countries, million and billions of dollars have been lost due the usage of mobile phones at the duty places. Usually the workers lose their concentration and they are unable to meet the targets. The usage of mobile phones has both positive and negative effects on students. In case of research, it has positive impact, while during class it has negative impact. The best way is to turn off mobile phones during working hours or during class in case of students, this will create positive image of mobile phones.

\section{Methodology of Research}

Collected data is primary and qualitative in nature. Data was collected from the students of UET Peshawar, Islamia College
University, University of Peshawar, and Agriculture University Peshawar; farmers; business community; and employees; all are from KPK, Pakistan. Structured questionnaire has been used as research tool and was distributed among the different classes. The primary data has been collected from the students of UET Peshawar, Islamia College University Peshawar, University of Peshawar, and Agriculture University Peshawar, KPK, for the class of students. The primary data of employees has been collected from various employees working in public sector as well as in private sector. The primary data of farmers has been collected from the farmers of district Karak, KPK. The primary data of business community has been collected from businessmen belonging to Peshawar and from the surrounding areas. The multienvironment means that various classes were selected from the population of KPK. Total enrolment of the people is 100 and 156 belonging to KPK, Pakistan. Few questions were asked by people and they were told to return to the questioner. Different frequencies and suitable percentage were used to explore the collected data.

Mobile phones usage by people, KPK, Pakistan, at duty sites and their impact on people will indicate dependency of the classes on mobile phone.

The overall study has followed the framework presented above, while the workflow diagram is presented in Figure 1.

3.1. Sample and Population. Based on the data collected from people in KPK, Pakistan, for this research study and to analyze collected data, students were selected from UET Peshawar, Islamia College University Peshawar, University of Peshawar, and Agriculture University of Peshawar, KPK, which include students from Electrical Engineering and Computer Engineering, because they have some basic knowledge of mobile communication, while other disciplines have their own domain in KPK. The primary data of farmers in KPK has been collected from the farmers of district Karak, $\mathrm{KPK}$, and business community in KPK, Pakistan. Data was collected from 100 people initially and later on from 156 people including students from UET Peshawar 32\%, farmers $23 \%$, business community $25 \%$, and employees $20 \%$. For presentation of the mobile phone applications, data is based on 32 students, 23 farmers, 25 businessmen, and 20 employees.

3.2. Observations Collection Tools. Primary data was collected through structured questionnaire from the students of UET Peshawar, Islamia College University Peshawar, University of Peshawar, and Agriculture University of Peshawar; farmers; employees; and business community, KPK, Pakistan. For data analysis, Excel was used. Observations collected through this tool have been analyzed by using suitable frequencies and percentages.

\section{Results and Discussion}

Primary data is collected through structured questionnaire from the students of UET Peshawar, farmers, employees, and business community, KPK, Pakistan. For data analysis, Excel was used. Observations collected through this tool have been analyzed by using suitable frequencies and percentages. 


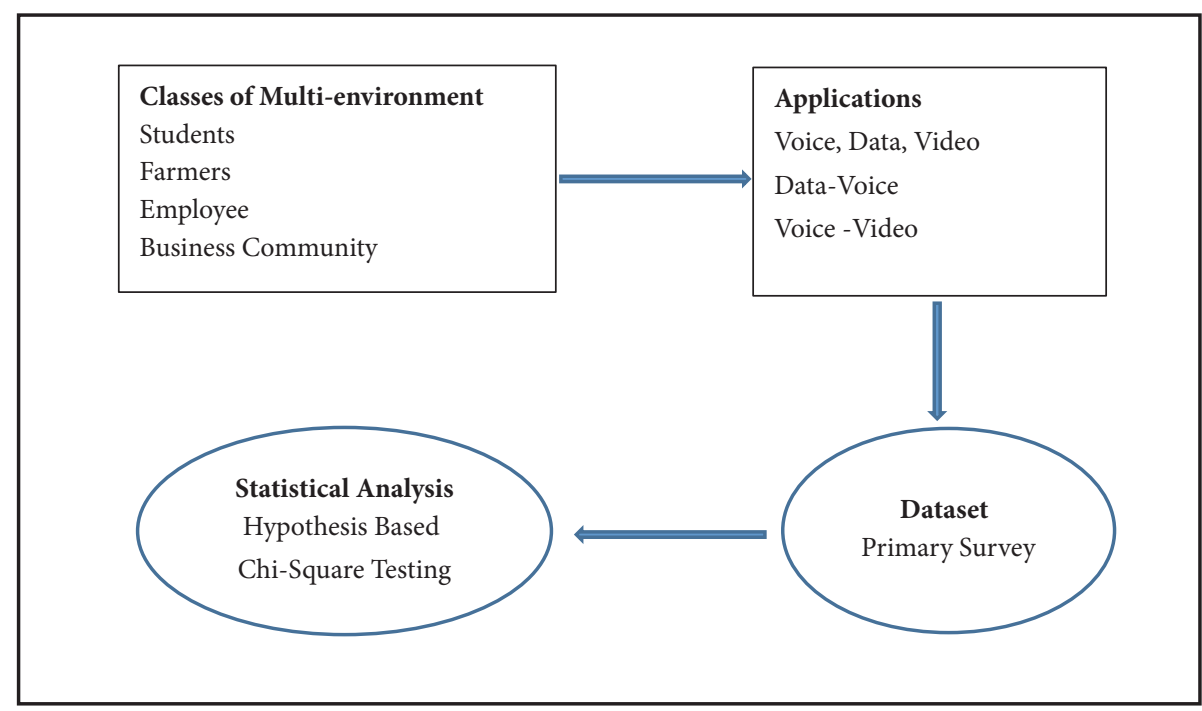

FIgURE 1: Overview of research model for mobile communication study.

TABLE 1: Statistical performance indices for all four classes on the basis of 100 samples.

\begin{tabular}{lccccccc}
\hline \multirow{2}{*}{ Application } & \multicolumn{3}{c}{ Multi-Environment Classes } & S & \multicolumn{2}{c}{ Statistical Indices } \\
& Students & Farmers & employees & Business & Mean & Variance & Standard Deviation \\
\hline Voice & 4 & 22 & 7 & 13 & 2.63 & 7.89 & 2.81 \\
Data & 3 & 1 & 4 & 2 & 2.50 & 7.50 & 2.74 \\
Data-Voice & 20 & 0 & 5 & 5 & 1.83 & 4.83 & 2.20 \\
Video & 3 & 0 & 4 & 2 & 2.56 & 7.89 & 2.81 \\
Voice-Video & 2 & 0 & 0 & 3 & 2.80 & 10.00 & 3.16 \\
\hline
\end{tabular}

TABLE 2: Statistical Performance indices for all four classes on the basis of dataset of 156 samples.

\begin{tabular}{lcccccccc}
\hline \multirow{2}{*}{ Application } & \multicolumn{3}{c}{ Multi-Environment Classes } & \multicolumn{5}{c}{ Statistical indices } \\
& Students & Farmers & Employees & Business & SUM & Mean & Variance & Standard Deviation \\
\hline Voice & 12 & 21 & 5 & 14 & 52 & 13 & 32.5 & 43.33 \\
Data & 18 & 0 & 6 & 3 & 27 & 6.75 & 46.68 & 6.83 \\
Data-Voice & 28 & 0 & 8 & 5 & 41 & 10.25 & 113.18 & 10.64 \\
Video & 1 & 9 & 2 & 2 & 14 & 3.5 & 10.25 & 3.2 \\
Voice-Video & 17 & 0 & 1 & 1 & 19 & 4.75 & 50.19 & 7.08 \\
SUM & 76 & 30 & 25 & 25 & & & & \\
\hline
\end{tabular}

The structured questioners consist of five variables, i.e., voice, data, data-voice, video, and voice-video. Based on the average response from the collected observations from farmers, business community, employees, and students of UET Peshawar, KPK, Pakistan, results are summarized in Tables 1 and 2 for dataset based on 100 samples and 156 samples, respectively, while graphical illustrations are presented in Figures 2 and 3 based on classes and application, respectively, for dataset based on 100 samples. Additionally, the graphical illustration results are presented in Figures 4-11 for dataset based on 156 samples in terms of pie graphs and cluster charts.

It is seen from the results presented for 100 samples based dataset that the high value of mean, i.e., 2.80, shows that the people use cell phones mostly for voice-video, which predicts the increased communication among peoples, as well as their behavior toward mobile phones. The 2 nd value of mean, i.e., 2.63 , for the voice shows that people use cell phones for voice, which indicates the positive attitude toward cell phone usage. It means that that people are well connected. The 3 rd value of the mean, i.e., 2.56, for the application of video shows that people use mobile phone for enjoyment and entertainment which may be harmful during working hours. The 4 th value of mean, i.e., 2.50, shows that people use mobile phones for data such as downloading data for research, literature, and stories. The 5 th value of the mean, i.e., 1.83, shows that people use cell phones for data-voice, which is at the lowest level, and thus one may say that most people have no smart phones for data.

It is seen from the result presented for 156 samples based dataset that the high value of mean, i.e., 13 , shows that people 


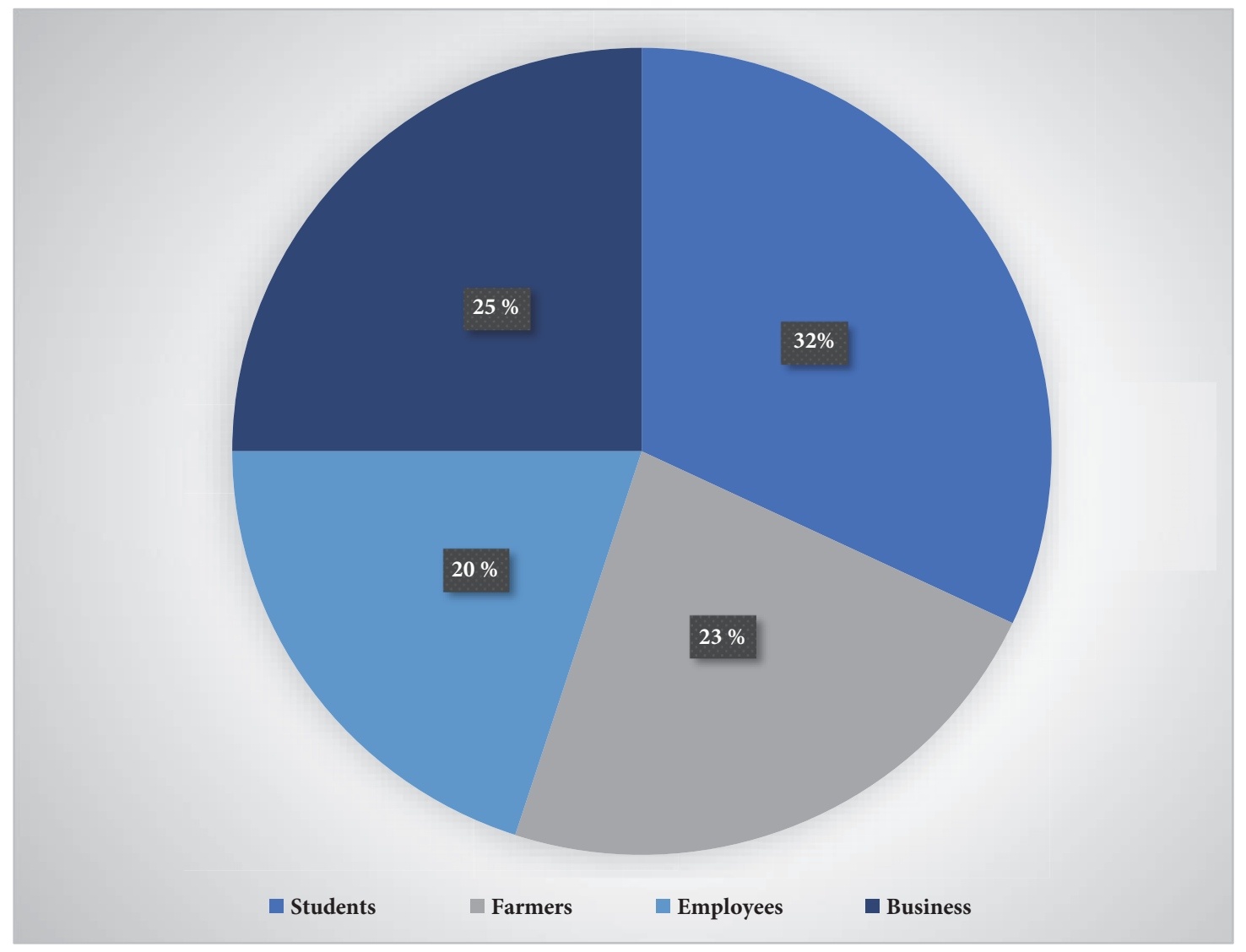

FIGURE 2: Pie-Chart based graphical illustration of the results for each class based on dataset of 100 samples.

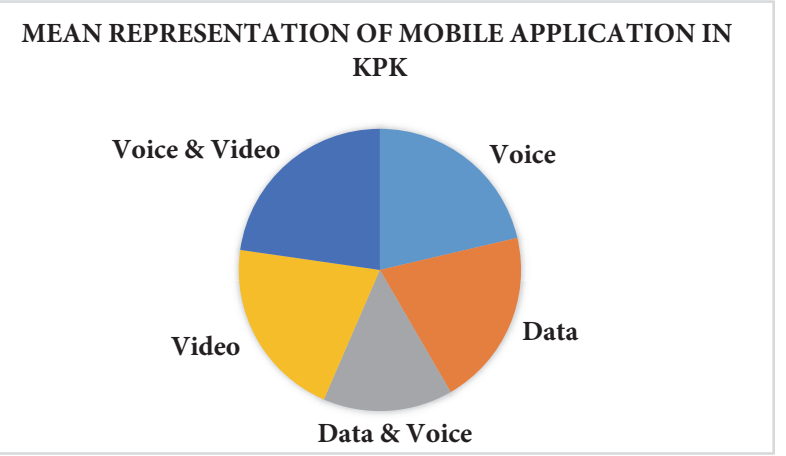

FIGURE 3: Pie-Chart based graphical illustration of the results for each application based on dataset of 100 samples.

use cell phones mostly for voice, which predicts the increased communication among people, as well as their behavior toward mobile phone. The 2 nd value of mean, i.e., 10.25 , for the data-voice shows that people use cell phone for voice as well as data, which indicates the positive attitude toward cell phone usage. It means that people are well connected. The 3rd value of the mean, i.e., 6.75, for the application of data shows that the people use mobile phones for enjoyment and entertainment, which may be harmful during working hours. The 4 th value of mean, i.e., 4.75 , shows that the people use mobile phones for data such as entertainment and voice calling. The 5 th value of the mean, i.e., 3.5, shows that people use cell phone for only video, which is at the lowest level, and thus one may say that most peoples have no smart phones for only video.

\section{Conclusion}

Based on the new technologies and new feature, mobile phone became integral part of our life. At work places, people have serious concern about mobile phone. Side SMS by student during class timing can waste the time of the students. This research has been carried out to predict the trend of mobile phone application among people of Pakistan. Observations were collected by questioner from students of UET Peshawar, Islamia College University Peshawar, University of Peshawar, and Agriculture University of Peshawar; farmers; business community; and employees. Analysis indicates that most students use mobile phones for voice conversion with family and coworkers. Mobile phones can be used for entertainment and text messaging. The result tabulated indicates that most people claim that they are not disturbed due to mobile phone. However, they would prefer to turn off their mobile phone during working hours. Most students receive around ten calls in average, which is comparatively high number. Based on the analysis from the observations 


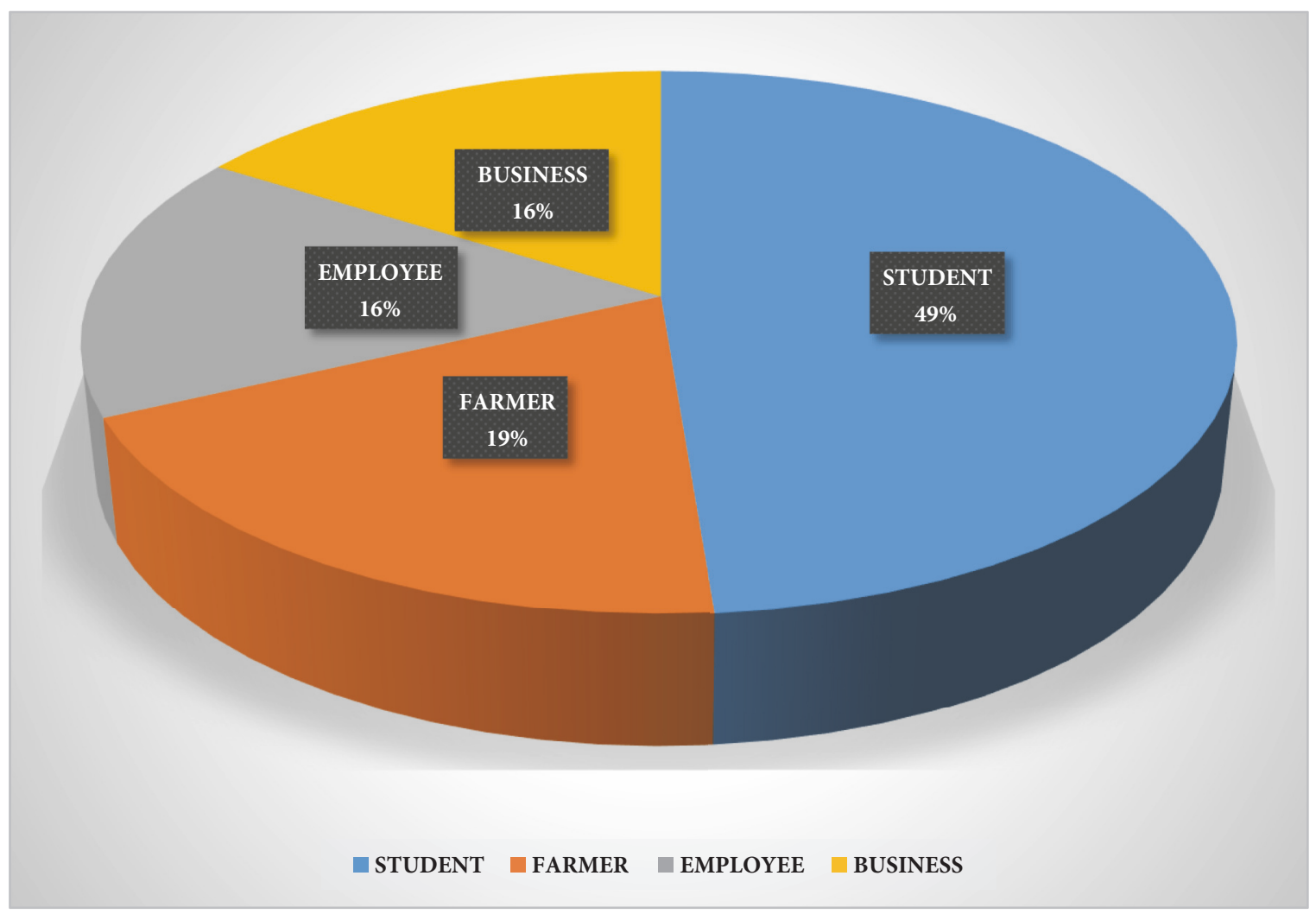

Figure 4: Pie-Chart based graphical illustration of the results for each class based on dataset of 156 samples.

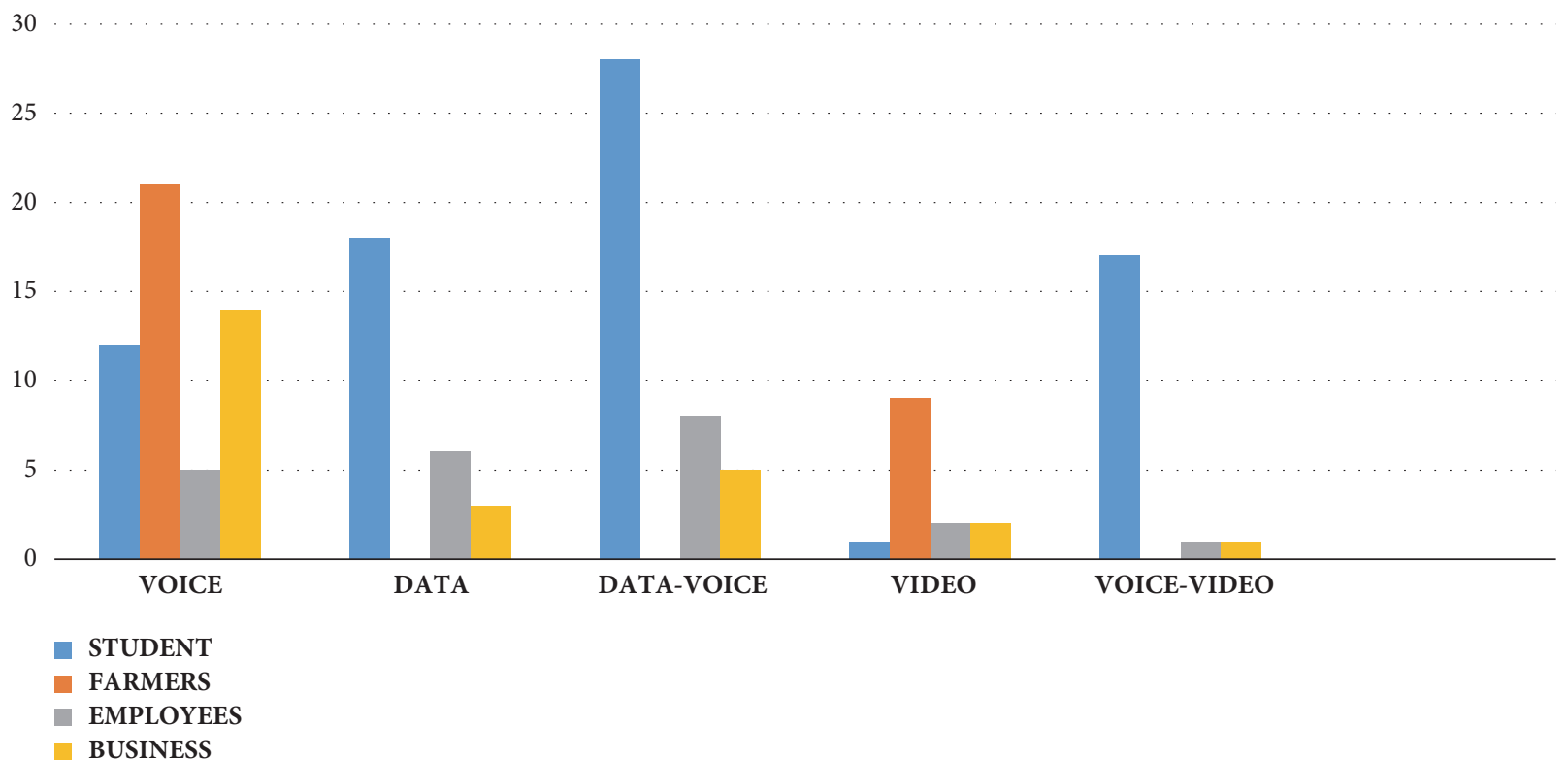

FIGURE 5: Cluster-Chart based graphical illustration of the results for each application based on dataset of 156 samples.

collected, over $50+$ percent of these calls are social in nature. These calls from mobile phones have increased the efficiency among the friends and families. Most of the mobile phones are not used for data.
A large number of people have the view that most of their work is related to mobile phones and their productivity is highly based on the usage of mobile phones, which shows the positive impact of mobile phones. 


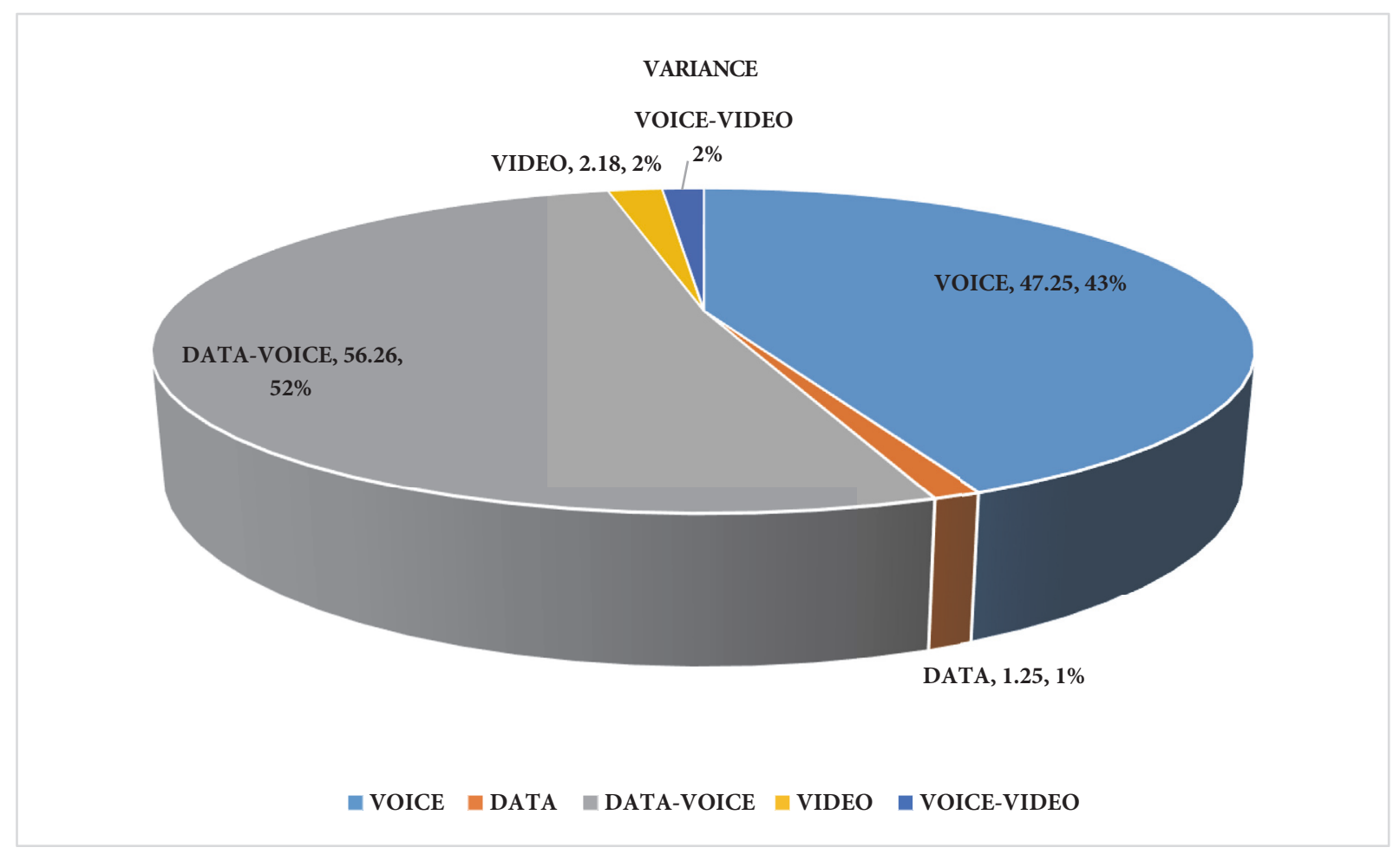

FIgURE 6: Pie-Chart based graphical illustration of the results for each application based on dataset of 156 samples.

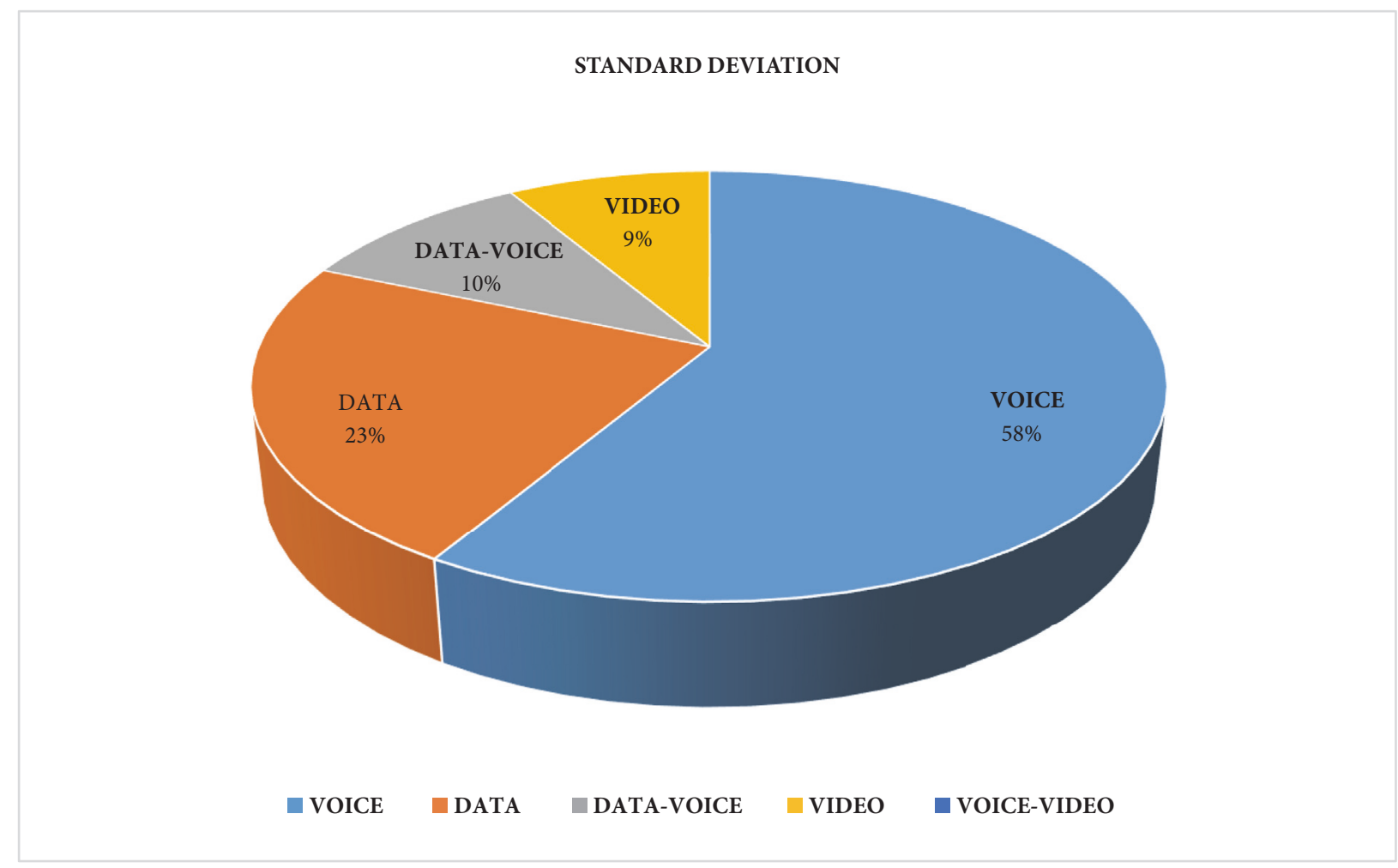

Figure 7: Pie-Chart based graphical illustration of the results for each application based on dataset of 156 samples. 


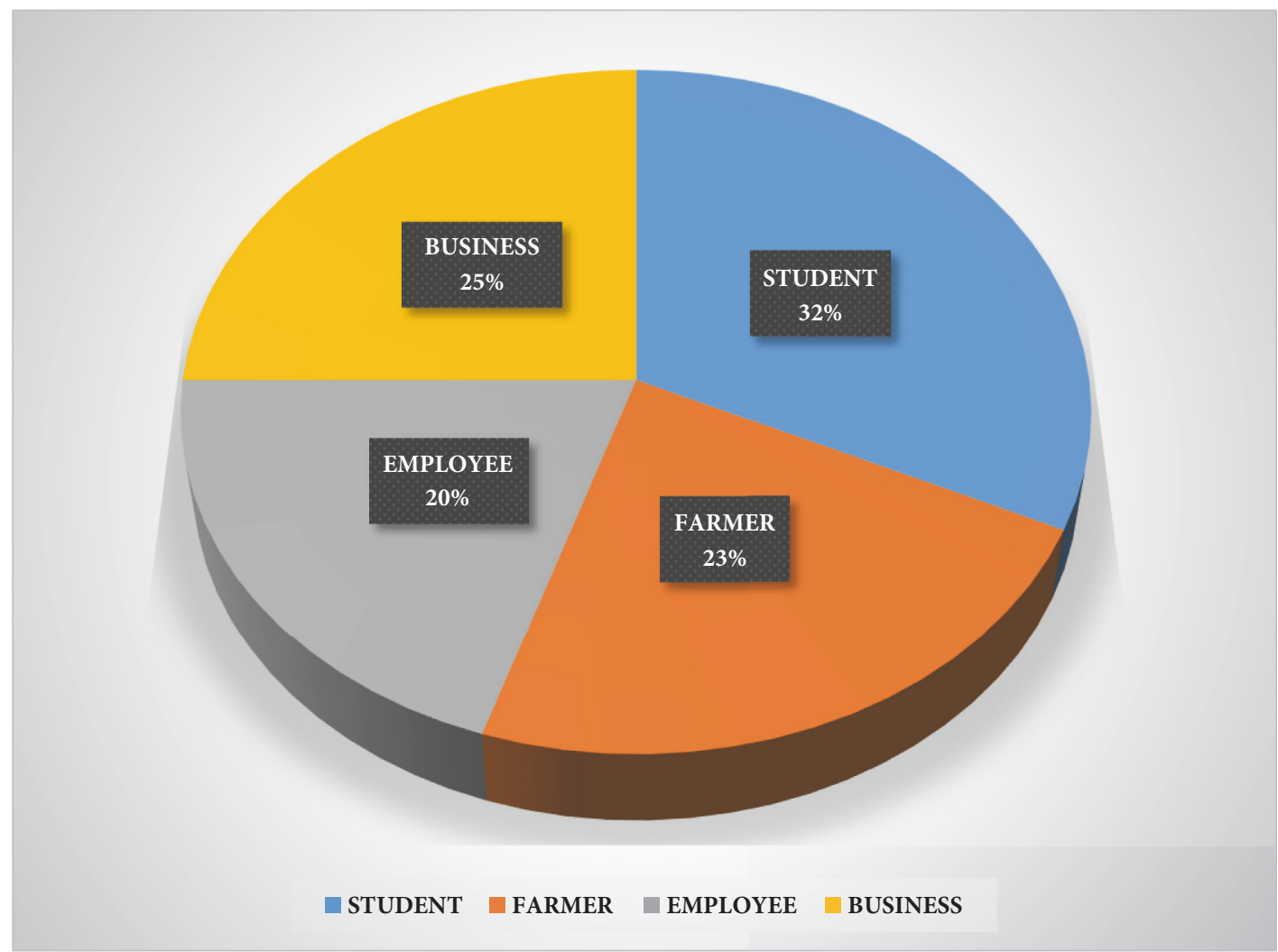

FIGURE 8: Pie-Chart based graphical illustration of the results for each class based on dataset of 156 samples.

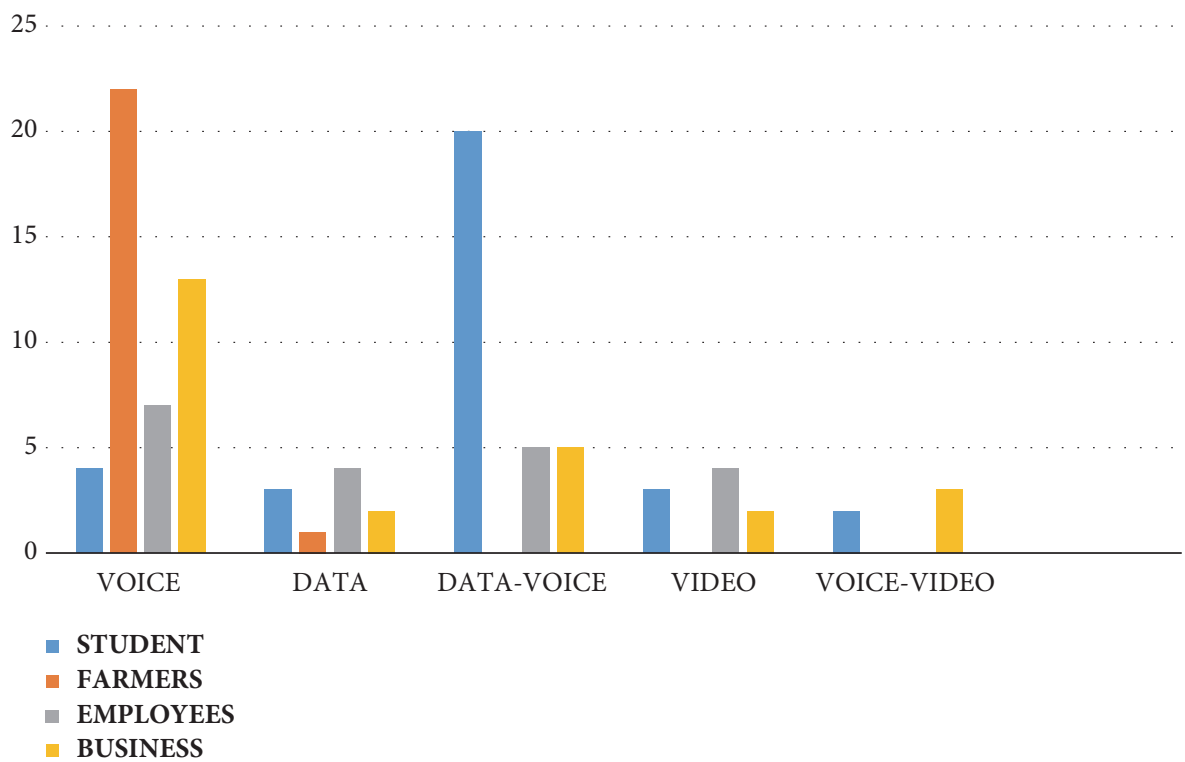

FIGURE 9: Cluster-Chart based graphical illustration of the results for each application based on dataset of 156 samples.

The report based on the observations collected from the students indicates that the use of mobile phone has increased in all sectors of society including students and other classes of society. Dependency of mobile phones has increased in institutions like universities, companies, and other sectors of production. Mobile phone has made access to information easy especially in jobs related to information. The employers and the owners use the mobile phone for market information. Physical distance has decreased and the people are well connected.

One group of people considered that they cannot live without the mobile phones and they do not violate the 


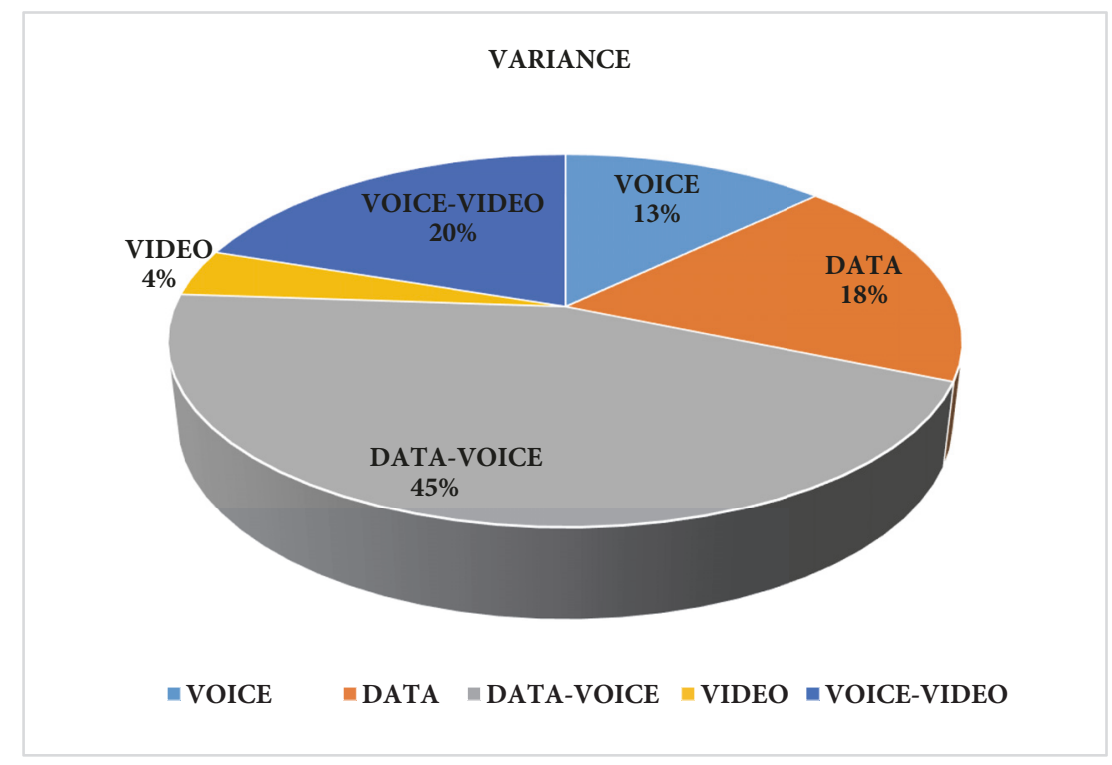

FIGURE 10: Pie-Chart based graphical illustration of the results for each application based on dataset of 156 samples.

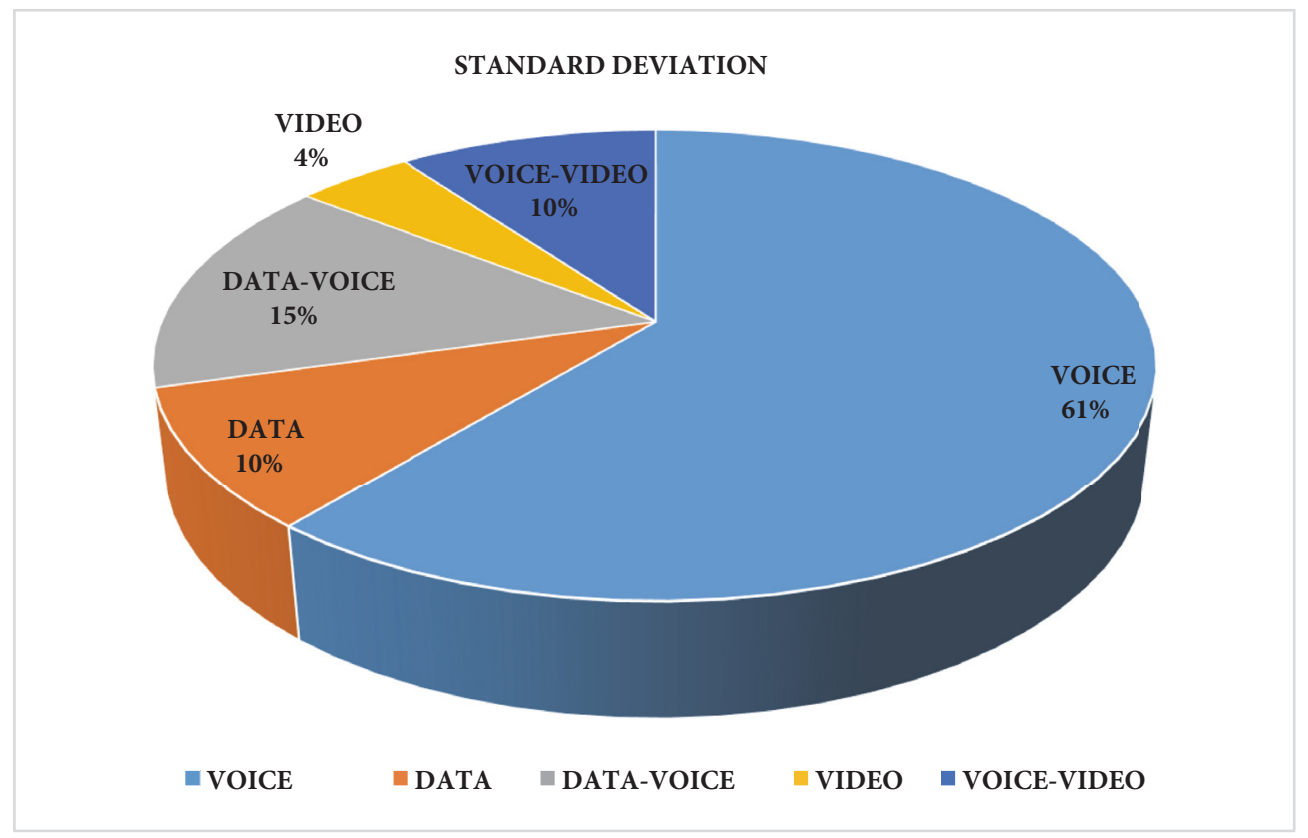

FIGURE 11: Pie-Chart based graphical illustration of the results for each application based on dataset of 156 samples.

standard procedures with ultimately increased productivity. The decisions based on these observations show that mobile phones can be used more productively.

At higher levels of management, the use of mobile phones is considered as positive change for business and corporate sectors. The mobile phones have developed good mutual relation of trust among the business community. A large number of people have the opinion that the mobile phone has brought a positive change in all fields of life. This research was based on the primary data collection, which was effective and result oriented, and it predict trends and policy for users from different classes.
In future, one may investigate neural networks [21-26] based methodologies for better planning, prediction, and policies for not only KPK region but also other similar regions all over the world.

\section{Appendix}

\section{Questionnaire}

Techno-Economic Impact of Mobile Communication on Society in Context of KPK, Pakistan. This questionnaire is developed for the survey of my Ph.D. research. The basic aim of this 
TABle 3: Demand side.

\begin{tabular}{lccccc}
\hline S.No & Description & 5 & 4 & 3 & 2 \\
\hline 1 & Age Group & $18-28$ & $29-38$ & $39-48$ & $49-68$ \\
2 & Working Class & Student & Farmer & Employee & Business \\
3 & Province & KPK & Sind & Punjab & Baluchistan \\
4 & Location of Living & Urban & Suburban & Normal Rural & No Demand \\
5 & Demand & Extreme & Needed & Good & No Quality \\
6 & Quality of Demand & Excellent & Better & & \\
\hline
\end{tabular}

TABLE 4: Supply side.

\begin{tabular}{lccccc}
\hline S.No & Description & 5 & 4 & 3 & Good \\
\hline 1 & Quality & Excellent & Better & No Quality \\
2 & Cost & Very High & High & Cheap \\
3 & Satisfaction & Excellent & Better & Good & Good \\
4 & Living & Excellent & Better & No & Normal at all \\
5 & Willing to pay & Yes & Up to some Extent & No & Not at all \\
6 & Employment opportunities & Yes & Upto some extent & Positive \& Negative & No. Impact \\
7 & Impact & Positive & Negative & No & Not at all \\
8 & Revenue Contribution & Yes & Upto Some extent & No & Not at all \\
9 & Need & Yes & No & &
\end{tabular}

TABLE 5: Mobile network side.

\begin{tabular}{lcccccc}
\hline S.No. & Description & 5 & 4 & 3 & 2 & Warid \\
\hline 1 & Mobile operator & Mobil ink & Telenor & Ufone & Zong \\
2 & Generation of Network & $4 \mathrm{G}$ & $3 \mathrm{G}$ & $2.5 \mathrm{G}$ & $2 \mathrm{G}$ & $1 \mathrm{G}$ \\
3 & Year of User & $1981-86$ & $1987-93$ & $1994-2000$ & $2001-2007$ & $2008-2014$ \\
4 & Application & Voice & Data & Data \& Voice & Video & Voice \& Video \\
\hline
\end{tabular}

survey is to collect the information of the technological growth of the mobile communication and the economic impact demand side, impact on supply side, impact on GDP, and impact on taxation on society. Your participation is highly needed in this dissertation survey.

Thanks. Shah Jahan Khattak Ph.D. Scholar

Gomal University, Dera Ismail khan/CESET, Islamabad. $\begin{array}{ll}1 & \text { Name } \\ 2 & \text { Gender } \\ 3 & \text { Marital Status }\end{array}$

See Tables 3, 4, and 5 .

\section{Data Availability}

The data used to support the findings of this study are included within the article.

\section{Conflicts of Interest}

All the authors of the manuscript declared that there are no potential conflicts of interest.

\section{References}

[1] M. Castells, M. Fernandez-Ardevol, J. L. Qiu, and A. Sey, "Mobile Communication and Society: A Global Perspective," Economic Geography, vol. 84, no. 1, pp. 119-120, 2008.
[2] M. Myint, A. Adam, S. Herath, and G. Smith, "Mobile phone applications in management of enuresis: The good, the bad, and the unreliable!," Journal of Pediatric Urology, vol. 12, no. 2, pp. 112-112.e6, 2016.

[3] R. Whittaker, R. Borland, C. Bullen, R. Lin, H. McRobbie, and A. Rodgers, "Mobile phone-based interventions for smoking cessation," Cochrane Database of Systematic Reviews, no. 3, 2007.

[4] L. F. Garabedian, D. Ross-Degnan, and J. F. Wharam, "Mobile Phone and Smartphone Technologies for Diabetes Care and Self-Management," Current Diabetes Reports, vol. 15, no. 12, article no. 109, 2015.

[5] M. Stanley, Y. Huang, T. Loh, Q. Xu, H. Wang, and H. Zhou, "A high gain steerable millimeter-wave antenna array for $5 \mathrm{G}$ smartphone applications," in Proceedings of the 11th European Conference on Antennas and Propagation, EUCAP 2017, pp. 1311-1314, March 2017. 
[6] Y. Yuan, M. Raubal, and Y. Liu, "Correlating mobile phone usage and travel behavior - A case study of Harbin, China," Computers, Environment and Urban Systems, vol. 36, no. 2, pp. 118-130, 2012.

[7] A. Backholm, M. Tervahauta, S. Salorinne et al., "Seven Networks Inc," in Dynamic adjustment of keep-alive messages for efficient battery usage in a mobile network, pp. 15-883, U.S. Patent Application, 2018.

[8] A. Orsino, A. Ometov, G. Fodor et al., "Effects of Heterogeneous Mobility on D2D- and Drone-Assisted Mission-Critical MTC in 5G," IEEE Communications Magazine, vol. 55, no. 2, pp. 79-87, 2017.

[9] P. Rost, C. Mannweiler, D. S. Michalopoulos et al., "Network Slicing to Enable Scalability and Flexibility in 5G Mobile Networks," IEEE Communications Magazine, vol. 55, no. 5, pp. 72-79, 2017.

[10] A. Lepp, J. E. Barkley, and A. C. Karpinski, "The relationship between cell phone use, academic performance, anxiety, and Satisfaction with Life in college students," Computers in Human Behavior, vol. 31, no. 1, pp. 343-350, 2014.

[11] L. Leung, "Leisure boredom, sensation seeking, self-esteem, and addiction: Symptoms and patterns of cell phone use," in Mediated Personal Communication, S. B. Barnes, E. A. Konijn, M. Tanis, and S. Utz, Eds., pp. 359-381, Routledge, New York, NY, USA, 2008.

[12] R. K. Donya, "Cellular Phone Usage and Productivity among Employees in A Ghanaian SME: An Assessment," International Journal of Computing and ICT Research, vol. 5, no. 1, pp. 21-34, 2011.

[13] R. W. Hahn and J. E. Prieger, "The impact of driver cell phone use on accidents," The BE Journal of Economic Analysis \& Policy, vol. 6 , no. 1,2006 .

[14] R. C. Nickerson, H. Isaac, and B. Mak, "A multi-national study of attitudes about mobile phone use in social settings," International Journal of Mobile Communications, vol. 6, no. 5, pp. 541-563, 2008.

[15] D. J. Reid and F. J. M. Reid, "Text or talk? Social anxiety, loneliness, and divergent preferences for cell phone use," Cyberpsychology, Behavior, and Social Networking, vol. 10, no. 3, pp. 424-435, 2007.

[16] C. Fisher, "Cardiologists embrace new terminology," BMJ, vol. 330, no. 7501, p. 1207, 2005.

[17] N. Cohen, "What Works: Grameen Telecom's Village Phones? A Digital dividend Study By The World Resources Institute," in World Resources Institute-Digital Dividend, 2001.

[18] B. Schackner, "More students opt for wireless phone: colleges face loss of commissions," in Knight Rider Tribune Business News, 2002.

[19] J. Chan, Z. Chen, I. Cormane, N. Her, and R. Thomas, "Cell phone industry analysis," in The multidimensional benefit of mobile technology in the developing world, Diego R., Ed., ICT for Development Community, 2006.

[20] M. N. Baliamoune, "The new economy and developing countries: Assessing the role of ICT diffusion," WIDER Discussion Papers//World Institute for Development Economics (UNUWIDER) 2002/77, 2002.

[21] Y. Wang, R. Li, H. Zhang, H. Tan, and Q. Chai, "Using SentenceLevel Neural Network Models for Multiple-Choice Reading Comprehension Tasks," Wireless Communications and Mobile Computing, vol. 2018, Article ID 2678976, 8 pages, 2018.

[22] B. Tang, J. Hu, X. Wang, and Q. Chen, "Recognizing Continuous and Discontinuous Adverse Drug Reaction Mentions from
Social Media Using LSTM-CRF," Wireless Communications and Mobile Computing, vol. 2018, Article ID 2379208, 8 pages, 2018.

[23] G. Q. Yang, "Multilayer Learning Network for Modulation Classification Assisted with Frequency Offset Cancellation in Satellite to Ground Link," Wireless Communications and Mobile Computing, vol. 2018, Article ID 1372439, 13 pages, 2018.

[24] M. Kanaan and M. Suveren, "In-body ranging with ultrawideband signals: Techniques and modeling of the ranging error," Wireless Communications and Mobile Computing, vol. 2017, Article ID 4313748, 15 pages, 2017.

[25] Q. Zhao, S. Lyu, B. Zhang, and W. Feng, "Multiactivation Pooling Method in Convolutional Neural Networks for Image Recognition," Wireless Communications and Mobile Computing, vol. 2018, Article ID 8196906, 15 pages, 2018.

[26] M. A. Raja, A. Mehmood, A. u. Rehman, A. Khan, and A. Zameer, "Bio-inspired computational heuristics for Sisko fluid flow and heat transfer models," Applied Soft Computing, vol. 71, pp. 622-648, 2018. 


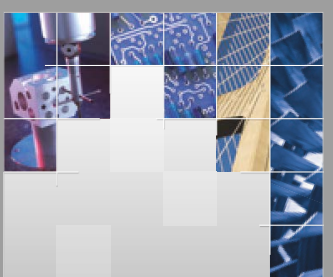

\section{Enfincering}
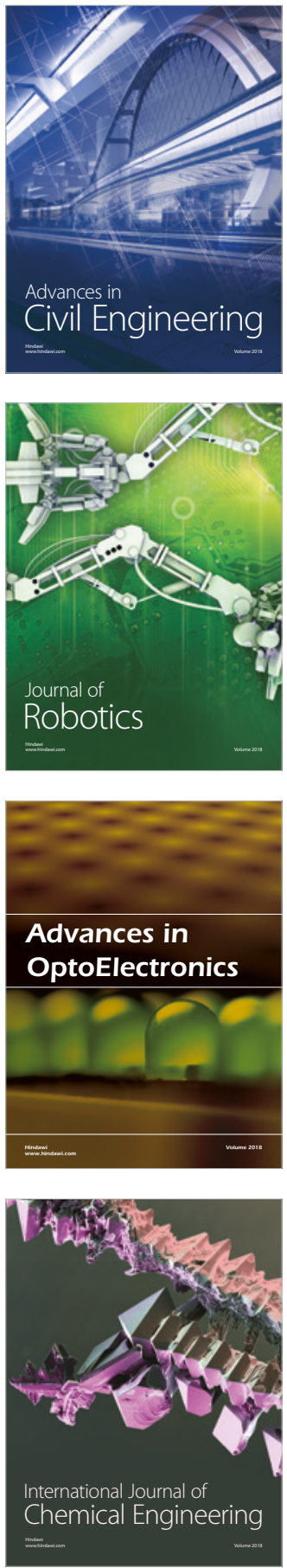

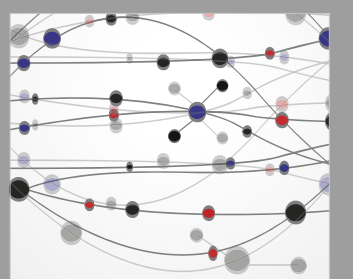

\section{Rotating \\ Machinery}

The Scientific World Journal

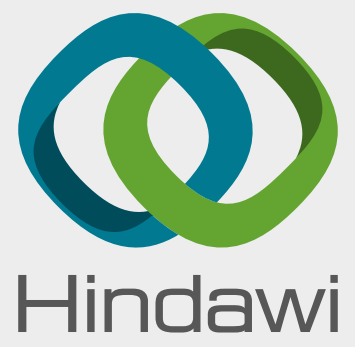

Submit your manuscripts at

www.hindawi.com
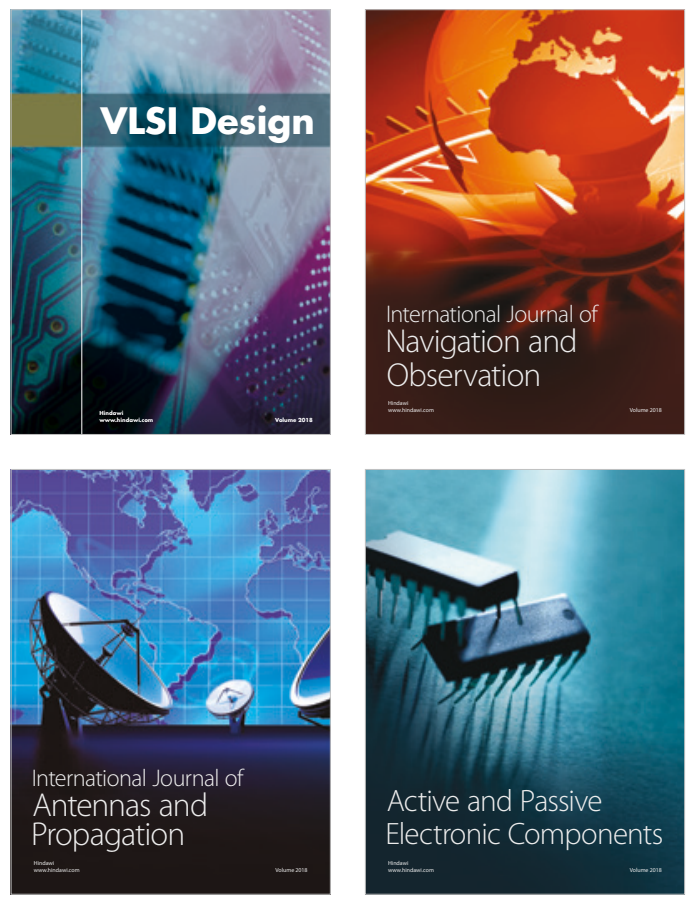
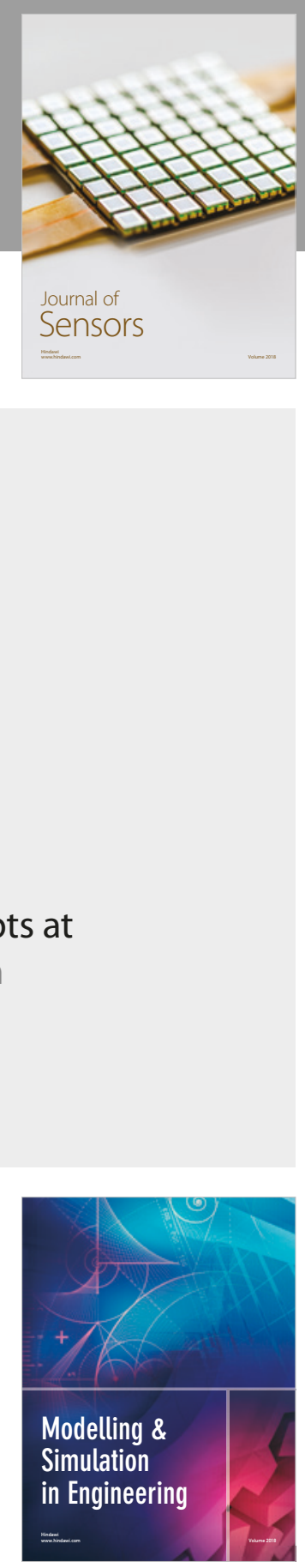

\section{Advances \\ Multimedia}
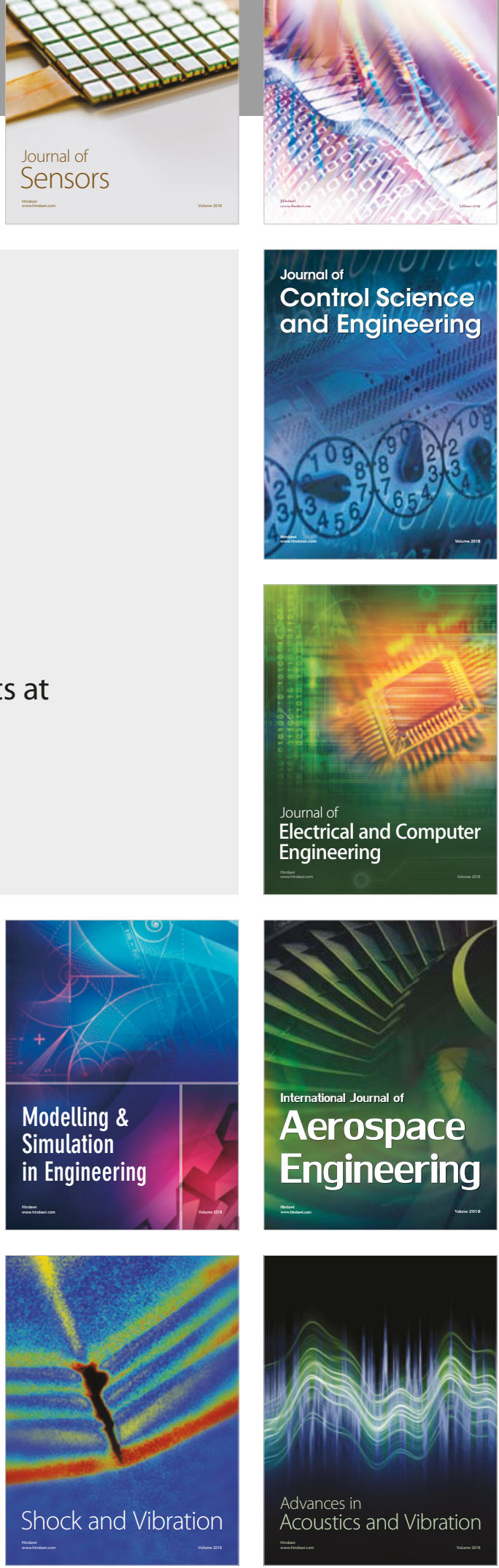